\title{
EVALUASI PELAKSANAAN KEGIATAN UPKD ANDALAS UNTUK SEKTOR PERTANIAN DARI DANA BENGKULU REGIONAL DEVELOPMENT PROJECT (BRDP) DI DESA TAPAK GEDUNG KABUPATEN KEPAHIANG
}

\author{
Nurhayatin Nufus 1 \\ Musriyadi Nabiu 1 \\ Tati Susilawati 2 \\ 1 Staff Pengajar Jurusan Sosial Ekonomi Pertanian Fak.Pertanian UNIB \\ 2 Alumni Jurusan Sosial Ekonomi Pertanian Fak.Pertanian UNIB
}

\begin{abstract}
This research was aimed at exploring the implementation of economic scheme program at UPKD Andalas and analyzing income discrepancy between member and non-member of UPKD Andalas. This research was conducted at UPKD Andalas District Kepahiang. Data was collected to 27 members and 21 non-members. These respondents were classified into paddy and coffee farmers. The results show that the implementation of economic scheme program was not running optimal yet which is indicated by unimplemented the rights and dutiesl. Rank spearman test show tyha relationship between the implementation level of the program and farmer income. However, there is insignificant income discrepancy between member and non-member incomes.
\end{abstract}

Key words : Evaluation, UPKD, agricultural

\section{PENDAHULUAN}

Dalam rangka meningkatkan taraf hidup masyarakat pedesaan dan mendukung upaya pengentasan kemiskinan, pertumbuhan ekonomi serta mendukung kelestarian lingkungan hidup di propinsi Bengkulu, pemerintah melaksanakan Proyek Pengembangan Wilayah Bengkulu (Bengkulu Regional Development Project/BRDP) yang sebagian dananya dibiayai dari Bank Dunia yang sifatnya soft loan dengan jangka waktu pengembalian yang cukup panjang.Setiap wilayah proyek BRDP berupa desa, membentuk suatu Unit Pengelola Keuangan Desa (UPKD), sebagai ujung tombak atau unit terkecil koordinasi proyek tersebut. Dana yang digulirkan akan disalurkan langsung kepada kepala desa lokasi proyek dan menjadi aset desa. Pengertian aset desa disini adalah berupa dana maksimum 200 juta per desa dan dikelola dengan cara kredit dengan bunga pinjaman $18 \%$ per tahun. Aset desa tersebut dimanfaatkan bagi pelaksanaan Program Kegiatan Desa (PKD), yang dikelola oleh UPKD. Seperti pada UPKD Andalas di Desa Tapak Gedung yang kegiatan utamanya adalah simpan pinjam untuk program ekonomi produktif terutama untuk sektor pertanian. 
Walaupun proyek ini diprioritaskan untuk sektor pertanian tetapi tidak semua petani menjadi anggota UPKD. Petani yang menjadi anggota adalah petani kopi dan petani padi sawah. Kedua komoditi ini merupakan komoditi utama yang diusahakan penduduk desa. Berbeda dengan petani non anggota, petani anggota terikat kesepakatan dengan UPKD untuk melaksanakan hak dan kewajibannya sebagai anggota. Terimplementasinya pelaksanaan hak dan kewajiban anggota akan membawa keuntungan bagi kedua pihak, sehingga dapat meningkatkan perekonomian desa. Tulisan ini bertujuan untuk untuk mengetahui pelaksanaan hak dan kewajiban kegiatan simpan pinjam sektor pertanian pada UPKD Andalas serta faktor apa saja yang mendukung dan menghambat pelaksanaan kegiatan tersebut, hubungan tingkat pelaksanaan hak dan kewajiban dengan Penerimaan anggota UPKD Andalas, serta perbedaan penerimaan usahatani antara petani anggota dan non anggota UPKD Andalas.

\section{METODE PENELITIAN}

Pemilihan daerah penelitian ini dilakukan secara sengaja (purposive sampling), yaitu UPKD Andalas Desa Tapak Gedung Kecamatan Tebat Karai Kabupaten Kepahiang. menggunakan data primer dan data sekunder. Data primer adalah data yang diperoleh dari responden melalui wawancara menggunakan kuesioner. Data sekunder adalah data yang diperoleh dari literatur seperti yang ada pada daftar pustaka, brosur UPKD Andalas, data monografi desa dan data-data yang ada di kantor UPKD Andalas.Populasi dalam penelitian ini terdiri dari dua sub populasi yaitu petani anggota dan petani non anggota UPKD Andalas. Dari masing-masing sub populasi petani tersebut mengusahakan tanaman kopi dan tanaman padi sawah. Dengan pertimbangan tersebut, maka jumlah Responden ditentukan secara Proportional Random Sampling, dimana besarnya Responden per sub populasi seperti pada Tabel 1 .

Tabel 1. Komposisi Jumlah Populasi dan Jumlah Responden

\begin{tabular}{cccccccccc}
\hline Strata & \multicolumn{3}{c}{ Populasi } & \multicolumn{7}{c}{ Responden } \\
& Petani Kopi & P. Padi & Total & Petani Kopi & P. Padi & Total & \\
\hline Anggota & & 44 & & 8 & 52 & & 23 & 4 & 27 \\
Non Anggota & 29 & & 12 & & 41 & & 15 & 6 & 21 \\
\hline Total & 73 & 20 & & 93 & & 38 & 14 & 48 \\
\hline
\end{tabular}

Evaluasi Pelaksanaan Hak dan Kewajiban Kegiatan Simpan Pinjam sektor Pertanian pada UPKD Andalas serta Faktor yang Mendukung dan menghambat pelaksanaannya.Untuk Mengevaluasi pelaksanaan dan untuk mengetahui faktor pendukung dan penghambat kegiatan pada UPKD Andalas digunakan analisa deskriptif, yaitu memberikan gambaran secara sistematis 
mengenai UPKD, termasuk tentang hubungan kegiatan-kegiatan, pandangan-pandangan dan pengaruhnya terhadap masyarakat. Sehingga dapat diketahui faktor apa saja yang mendukung dan menghambat pelaksanaan kegiatan tersebut.

Tingkat pelaksanaan dapat diukur dengan terlaksananya hak dan kewajiban sesuai dengan perjanjian di dalam buku petunjuk antara petani dan UPKD. Untuk melihat tingkat pelaksanaan yang dihubungkan dengan penerimaan usahatani petani maka digunakan analisa Rank Spearman (rs) (Siegel S, 1994). Dari total skor diseluruh jawaban yang dibuat, kemudian dibedakan dalam 3 kategori yaitu baik, cukup baiak dan tidak baik. Sedangkan perbedaan penerimaan usahatani anggota dan non anggota UPKD andalas dilakukan perbandingan antara penerimaan usahatani petani non anggota UPKD Andalas dilakukan dengan Uji-t .

\section{HASIL DAN PEMBAHASAN}

\section{Pelaksanaan Hak dan Kewajiban Kegiatan Simpan Pinjam Sektor Pertanian}

Kegiatan utama UPKD Andalas adalah simpan pinjam untuk sektor pertanian. Di mana komoditas utama yang diusahakan masyarakat desa ini adalah komoditas perkebunan kopi, padi sawah dan sayuran. Namun komoditas sayuran di desa ini hanya diusahakan sebagai usaha sampingan. Demikian pula petani anggota pada UPKD Andalas hanya meliputi petani yang mengusahakan tanaman kopi dan padi sawah. Dana digulirkan kepada masyarakat petani secara individu, karena masyarakat Desa Tapak Gedung memiliki usaha sendiri. Dana yang digulirkan untuk periode pertama peminjaman maksimal Rp. 1.500.000.

Dalam surat perjanjian secara umum hanya menjabarkan kewajiban pihak anggota sebagai pihak kedua. Kewajiban pihak UPKD bisa diartikan sebagai hak yang harus diterima pihak petani. Begitu pula kewajiban pihak petani bisa diartikan sebagai hak pihak UPKD (pihak pertama). Pemaparan hak dan kewajiban anggota sesuai petunjuk dapat dilihat pada Tabel 2.

Tabel 2. Kategori Penerapan Hak dan Kewajiban oleh Petani Anggota UPKD Andalas

\begin{tabular}{llll}
\hline \multirow{2}{*}{ No $\quad$ Hak dan Kewajiban } & \multicolumn{2}{c}{$\%$ Kategori Penerapan } & \multirow{2}{*}{ Keterangan } \\
\cline { 2 - 3 } & Ya & Kadang Tidak & \\
\hline
\end{tabular}




\begin{tabular}{|c|c|c|c|c|c|}
\hline 1 & $\begin{array}{l}\text { Pihak pertama mengikutsertakan pihak kedua } \\
\text { dalam mengambil keputusan yang berkaitan } \\
\text { dengan Progran Kegiatan Desa }\end{array}$ & 92,6 & 7,4 & 0 & $\begin{array}{l}\text { Untuk menen } \\
\text { tukan program } \\
\text { (awal program) }\end{array}$ \\
\hline 2 & $\begin{array}{l}\text { Pihak pertama memberikan kredit/ pinjaman } \\
\text { modal untuk usahatani pihak kedua sesuai } \\
\text { dengan surat persetujuan kredit }\end{array}$ & 59,3 & 33,3 & 7,4 & $\begin{array}{l}\text { Jika keuangan } \\
\text { mencukupi }\end{array}$ \\
\hline 3 & $\begin{array}{l}\text { Pihak pertama memberikan pembinaan dan } \\
\text { penyuluhan kepada petani }\end{array}$ & 26 & 51,8 & 22,2 & Tidak menyeluruh \\
\hline 4 & Pihak pertama mengelola dana kredit & 96,3 & 3,7 & 0 & \\
\hline 5 & $\begin{array}{l}\text { Pihak pertama mengikutsertakan pihak kedua } \\
\text { dalam musyawarah pengaturan SHU }\end{array}$ & 14,8 & 33,3 & 51,9 & $\begin{array}{l}\text { Tidak melibatkan } \\
\text { anggota }\end{array}$ \\
\hline 6 & $\begin{array}{l}\text { Pihak kedua mengajukan permohonan } \\
\text { pinjaman kepada pihak pertama }\end{array}$ & 100 & 0 & 0 & $\begin{array}{l}\text { Blanko disiapkan } \\
\text { UPKD }\end{array}$ \\
\hline 7 & Pihak kedua menyerahkan agunan pinjaman & 70,3 & 26 & 3,7 & Untuk kedisplinan \\
\hline 8 & $\begin{array}{l}\text { Pihak kedua wajib membayar angsuran kredit } \\
\text { dan bunganya }\end{array}$ & 100 & 0 & 0 & $\begin{array}{l}\text { Sistem } \\
\text { kebersamaan }\end{array}$ \\
\hline 9 & $\begin{array}{l}\text { Pihak kedua menyimpan uang/ menanam } \\
\text { saham }\end{array}$ & 74 & 26 & 0 & $\begin{array}{l}\text { Kewajiban } \\
\text { sebagai anggota }\end{array}$ \\
\hline 10 & $\begin{array}{l}\text { Pihak kedua dikenakan denda jika terjadi } \\
\text { keterlambatan ansuran }\end{array}$ & 85,2 & 7,4 & 7,4 & Merupakan sanksi \\
\hline
\end{tabular}

Sumber : Data Primer diolah 2004

Tabel 2 menunjukkan bahwa hak dan kewajiban yang telah disepakati oleh kedua belah pihak belum semuanya terpenuhi. Sebelum menentukan program desa pihak UPKD mengikutsertakan masyarakat untuk mengambil keputusan, program apa yang akan dilaksanakan. Dimulai dari proses sosialisasi, pembentukan UPKD dan pemilihan ketua serta dalam menentukan kegiatan sarana dan prasarana. Melihat dari kegiatan yang melibatkan masyarakat tersebut dapat dikatakan bahwa aspek ini sudah dilaksanakan $(92,6 \%)$.

Petani yang mengusulkan sejumlah pinjaman kredit tidak semuanya dapat disetujui. Walaupun 59,3 \% anggota menyetujuinya, namun 33,3 \% masih dalam kategori kadang-kadang. Hal ini karena selain berdasarkan studi kelayakan rumah tangga, juga disebabkan keadaan keuangan yang ada. Ini berarti bahwa meskipun proposal layak, namun keuangan UPKD tidak mencukupi maka diberikan pinjaman sesuai dengan kemampuan keuangan UPKD dan kebutuhan anggota. Kegiatan pembinaan dan penyuluhan kepada petani anggota tidak dilakukan secara menyeluruh, 51,8 \% anggota mengakui hal itu. Proses pembinaan dan penyuluhan dilakukan hanya sewaktu-waktu (sesuai kebutuhan), itupun dilakukan secara umum. Dana yang berasal dari proyek BRDP dan dari masyarakat, dikelola dengan baik oleh pihak UPKD. Hal ini didukung 96,3\% anggota berada pada kategori setuju. Pengelolaan dana tersebut melalui sistem kredit dengan bunga pinjaman $18 \%$ per tahun. Adapun jangka waktu pengembalian untuk jumlah S) 
lebih kecil atau sama dengan Rp. 500.000 selama 6 bulan dan untuk jumlah yang lebih besar yaitu 10 sampai 12 bulan.

Dari hasil wawancara diketahui bahwa mayoritas anggota (51,9\%) tidak mengetahui tentang Sisa Hasil Usaha (SHU). Ketidaktahuan anggota ini dikarenakan kurangnya sosialisasi mengenai SHU dari Pengurus UPKD. Sehingga anggota tidak perna mengikuti musyawarah dalam pengaturan SHU. Menurut pengurus UPKD, pengaturan SHU ini tidak mengikutsertakan anggota karena pembagian SHU memang belum dilaksanakan mengingat SHU kembali digulirkan.

Setiap anggota (100 \%) mengajukan kredit harus di dahului oleh permohonan pinjaman yang disampaikan kepada pihak UPKD. Untuk itu calon peminjam harus mengisi blangko surat yang telah disediakan. Selanjutnya pengurus UPKD dan Pokja melaksanakan peninjauan dan verifikasi rumah tangga, apabila proposal dinyatakan layak maka anggota akan mendapatkan pinjaman modal usaha. Umumnya setiap kredit mengharapkan adanya agunan. Pada program UPKD 70,3 \% menyerahkan agunan. Agunan ini diberlakukan pada pinjaman lebih besar atau sama dengan Rp.1.000.000. Jenis agunan yang umum diserahkan adalah surat keterangan kepemilikan barang berharga seperti : sertifikat tanah, televisi dan mobil.

Petani anggota wajib membayar angsuran setiap bulannya (100\%). Namun dengan adanya sistem kebersamaan, maka untuk setiap bulannya petani anggota hanya membayar angsuran bunganya saja. Setiap bu;lannya petani menanggung beban bunga pinjaman sebesar $1,5 \%$ (18 \%/ Th) dari pokok pinjaman. Sedangkan untuk pengembalian pokok pinjaman dapat dilakukan pada saat panen tiba. Pada setiap masa angsuran anggota UPKD berkewajiban menyimpan uang/menanam saham pada UPKD minimal Rp.1.000 per bulan, setelah membayar simpanan pokok Rp. 7.500 (sebesar 74 \%). Selain simpanan wajib ada juga anggota yang menabung di UPKD (26\%). Namun tidak ada anggota yang menabung per bulannya lebih besar dari Rp.100.000. Begitu juga di luar masa angsuran, anggota tidak menyimpan uang di UPKD. Dengan demikian UPKD sebagai tempat penyimpanan uang belum berfungsi.Jika petani terlambat dalam membayar angsuran selama tiga periode angsuran ( 3 bulan) maka akan dikenakan sanksi berupa denda 1,5\% dari jumlah angsuran yang tertunda. Dan apabila petani anggota tidak sanggup melunasi kredit hingga batas waktu yang telah disepakati, maka jaminan di sita menjadi milik UPKD.

Faktor Pendukung dan Penghambat Pelaksanaan Kegiatan UPKD Andalas 
Sesungguhnya cukup sulit untuk mengetahui faktor-faktor apa yang mendukung dan menghambat pelaksanaan kegiatan UPKD Andalas untuk sektor pertanian. Namun berdasarkan pada pengalaman pelaksanaan di lapangan dapat diketahui hal-hal yang mendukung dan menghambat keberhasilan pelaksanaan kegiatan. Adapun faktor yang mendukung keberhasilan pelaksanaan kegiatan yaitu :

1. Mayoritas masyarakat membutuhkan modal untuk usahatani dan untuk meningkatkan penerimaan.

2. Pihak UPKD memberikan pinjaman dengan prosedur yang sederhana.

3. Adanya tenaga ahli dari proyek BRDP yang melakukan fungsi penyuluhan

4. Adanya prinsip kebersamaan

5. Surat perjanjian pelaksanaan yang memungkinkan untuk mengurangi tunggakan.

6. Adanya tenaga pemasaran yang memudahkan petani dalam pemasaran produknya.

Sedangkan faktor-faktor yang menghambat pelaksanaan kegiatan simpan pinjam untuk sektor pertanian pada UPKD Andalas adalah :

1. Kurangnya sosialisasi dari pihak UPKD mengenai hak dan kewajiban anggota

2. Penyuluhan tidak dilakukan secara menyeluruh.

3.Bantuan untuk petani hanya berbentuk dana bergulir, sehingga memungkinkan petani menyalahgunakan dana kredit.

Tingkat Pelaksanaan Hak dan Kewajiban Kegiatan Simpan Pinjam pada UPKD Andalas untuk Petani Kopi dan Petani Padi Sawah Dalam penelitian ini, tingkat pelaksanaan diartikan sebagai suatu ukuran yang menunjukkkan tingkat keberhasilan pelaksanaan hak dan kewajiban kegiatan simpan pinjam yang saling menguntungkan sesuai dengan kesepakatan. Untuk lebih jelasnya tingkat pelaksanaan kegiatan yang dilakukan petani anggota UPKD Andalas dapat dilihat pada Tabel 3

Tabel 3. Tingkat Pelaksanaan Hak dan Kewajiban pada Kegiatan Simpan Pinjam

\begin{tabular}{lccc}
\hline \multicolumn{1}{c}{ Kategori tingkat pelaksanaan } & Persentase & $\begin{array}{c}\text { Rata-rata } \\
\text { Skor }\end{array}$ & $\begin{array}{c}\text { Kisaran } \\
\text { Skor }\end{array}$ \\
\hline 1. Petani Kopi & & 42,52 & $36-48$ \\
Baik $(\geq 44,2065)$ & 21,7 & & \\
Cukup baik $(40,8375<X<44,2065)$ & 47,8 & & \\
Tidak baik $(\leq 40.8375)$ & 30,4 & & \\
2. Petani Padi & & 42,5 & \\
Baik $(\geq 45)$ & 25 & & \\
\hline
\end{tabular}

Evaluasi Pelaksanaan Kegiatan UPKD Andalas Untuk Sektor Pertanian S) 


\begin{tabular}{lc}
\hline Cukup baik $(40<X<45)$ & 50 \\
Tidak baik $(\leq 40)$ & 25 \\
\hline Sumber : Data primer diolah 2004 & Ket : $X=$ tingkat palaksanaan
\end{tabular}

Tabel 3 menunjukan bahwa kedua jenis komoditi yang diusahakan oleh petani anggota terbesar adalah memiliki tingkat pelaksanaan cukup baik. Uraian tersebut didukung oleh kenyataan dilapangan bahwa kebutuhan petani anggota untuk memperoleh kredit dalam menjalankan usahataninya tinggi. Namun disisi lain, tingkat pelaksanaan kegiatan usahatani petani kopi yang tidak baik mencapai 30,4 \% dan petani padi $25 \%$. Hal ini menunjukan bahwa hak dan kewajiban yang telah disepakati belum terimplementasi dengan baik. Tingkat pelaksanaan baik untuk petani kopi 21,7\%, sedangkan petani padi mencapai $25 \%$. Tingkat pelaksanaan dalam kategori baik ini terjadi karena petani telah merasakan manfaat memiliki lembaga UPKD sebagai milik bersama yang dapat membantu petani dalam kegiatan usahataninya.

\section{Hubungan Pelaksanaan Hak dan Kewajiban pada Kegiatan Simpan Pinjam Anggota UPKD Andalas Dengan Penerimaan Petani}

Hasil perhitungan koefisien korelasi rank spearman (rs) dapat dilihat pada Tabel 4 berikut.

Tabel 4. Hasil Perhitungan Uji Korelasi Rank Spearman dan Nilai t hitung antara Tingkat Pelaksanaan Kegiatan dengan Penerimaan Petani

\begin{tabular}{lcc}
\hline \multirow{2}{*}{ Keterangan } & \multicolumn{2}{c}{ Nilai } \\
\cline { 2 - 3 } & Petani Kopi & Petani Padi \\
\hline Koefisien korelasi & 0,58322 & 0,80000 \\
thitung & 3,292 & 0,800 \\
$\mathrm{rSh}_{\text {hitung }}$ & & 0,800 \\
$\mathrm{t}_{\text {tabel }}(\propto=0,05 \%, \mathrm{df}=\mathrm{N}-2=21)$ & 2,518 & 0,800 \\
$\mathrm{rS}_{\text {table }}(\mathrm{N}=4)$ & & $\left(^{*}\right)$ \\
Derajat Hubungan & $\left(^{*}\right)$ & \\
\hline
\end{tabular}

Ket $:\left(^{*}\right)=$ Berhubungan nyata pada tingkat kepercayaan $95 \%$ 
Dari Tabel 4 diatas, dapat disimpulkan bahwa adanya hubungan antara tingkat pelaksanaan kegiatan dengan penerimaan petani angota baik petani kopi maupun petani padi. Kegiatan simpan pinjam untuk petani kopi thitung $(3,292)$ lebih besar dari t tabel $(2,518)$, dan untuk petani padi rs hitung $(0,800)$ sama dengan rs tabel $(0,800)$. Hasil perhitungan menunjukkan adanya hubungan yang positif sehingga memberikan arti bahwa semakin tinggi tingkat pelaksanaan maka semakin tinggi pula penerimaan yang akan diterima petani. Hal serupa juga dikemukakan oleh Folia SA (2003), yang menyatakan ada hubungan yang positif antara tingkat pelaksanaan kemitraan dengan penerimaan yang diterima petani.

\section{Perbedaan Penerimaan Usahatani Petani Anggota dan Petani Non Anggota UPKD Andalas}

Penerimaan usahatani diukur dari hasil kali antara total produksi dengan harga, dalam satuan $\mathrm{Rp} / \mathrm{Ha} /$ thn untuk usahatani kopi dan $\mathrm{Rp} / \mathrm{Ha} / \mathrm{mt}$ untuk usahatani padi. Secara kuantitatif adanya perbedaan penerimaan petani anggota dan non anggota, baik petani kopi maupun petani padi. Penerimaan petani anggota lebih tinggi dari penerimaan petani non anggota. Namun perbedaan tersebut belum tentu berbeda secara statistik, mungkin saja kedua penerimaan tersebut berbeda kebetulan saja. Seperti hasil penelitian Gunawan I (2003), yang menyatakan bahwa secara kuantitatif rata-rata penerimaan usaha nelayan penangkap udang berbeda dan secara statistik tidak berbeda. Untuk membuktikan ada atau tidaknya perbedaan penerimaan petani anggota dan non anggota, maka digunakan Uji-t dengan cara menghitung standar error dari beda. Hasil perhitungan Uji- $t$ standar error dari beda dapat dilihat pada Tabel 5 berikut.

Tabel 5. Hasil Perhitungan Uji- t dengan Menghitung Standar Error dari Beda

\begin{tabular}{lcc}
\hline \multicolumn{1}{c}{ Keterangan } & \multicolumn{2}{c}{ Nilai } \\
\cline { 2 - 3 } & Petani Kopi & Petani Padi \\
\hline thitung & 1,863 & 1,049 \\
tabel $[(\mathrm{n} 1+\mathrm{n} 2)-2]$ & 2,436 & 2,896 \\
Derajat Perbedaan & Tidak Nyata & Tidak Nyata \\
\hline
\end{tabular}

Ket : Tingkat kepercayaan 95\% $(\alpha / 2=0,025)$

Pada Tabel 5 dapat diketahui bahwa tidak terdapat perbedaan yang nyata antara ratarata penerimaan petani kopi anggota dengan rata-rata penerimaan petani non anggota UPKD Andalas. Hal tersebut ditunjukan oleh nilai thitung $(1,863)$ yang lebih kecil dari t tabel $(2,436)$, ini berarti bahwa dengan menjadi anggota UPKD tidak ada jaminan dapat meningkatkan penerimaan yang akan diterima oleh petani kopi. 
Tabel 5 juga menunjukan bahwa rata-rata penerimaan petani padi anggota tidak memiliki perbedaan nyata dengan penerimaan petani non anggota. Hal tersebut ditunjukan oleh nilai $t$ hitung $(1,049)$ lebih kecil dari t tabel $(2,896)$, ini berarti bahwa walaupun menjadi anggota UPKD tidak menjamin penerimaan yang diterima oleh petani akan lebih besar. Hal ini sejalan dengan pendapat Lofty A (2001), yang menyatakan bahwa tingkat penerimaan usahatani padi sawah pada petani yang memanfaatkan KUT (penerima KUT) lebih kecil dibandingkan dengan tingkat penerimaan usahatani pada petani yang tidak memanfaatkan KUT (non penerima KUT). Namun berlawanan dengan pendapat Astuti (1997), yang menyatakan bahwa penerimaan petani sesudah menerima dana bantuan IDT lebih besar dari penerimaan petani sebelumnya.

\section{KESIMPULAN DAN SARAN}

\section{Kesimpulan}

1. Pelaksanaan hak dan kewajiban kegiatan simpan pinjam sektor pertanian pada UPKD Andalas belum berjalan secara optimal terbukti dengan adanya hak dan kewajiban yang belum terimplementasi. Adapun faktor pendukungnya adalah : (1) mayoritas masyarakat membutuhkan modal untuk usahatani dan untuk meningkatkan penerimaan. (2) Pihak UPKD memberikan pinjaman dengan prosedur yang sederhana. (3) adanya tenaga ahli dari proyek BRDP yang melakukan fungsi penyuluhan. (4) adanya prinsip kebersamaan. (5) surat perjanjian pelaksanaan yang memungkinkan untuk mengurangi tunggakan. (6) adanya tenaga pemasaran yang memudahkan petani dalam pemasaran produknya. Sedangkan faktor penghambatnya adalah : (1) kurangnya sosialisasi dari pihak UPKD mengenai hak dan kewajiban. (2) Penyuluhan tidak dilakukan secara menyeluruh. (3) bantuan untuk petani hanya berbentuk dana bergulir.

2 Tingkat pelaksanaan kegiatan simpan pinjam yang dilakukan oleh petani responden mayoritas termasuk dalam kategori cukup baik. Untuk petani kopi sebesar 47,8 \% dan petani padi sawah mencapai $50 \%$. Dari hasil perhitungan, nilai t hitung tingkat pelaksanaan petani kopi $(3,292)$ lebih besar dari nilai t tabel $(2,518)$. Sedangkan untuk petani padi nilai rs hitung $(0,800)$ sama dengan nilai rs tabel $(0,800)$. Hal ini menunjukkan ada hubungan tingkat pelaksanaan dengan penerimaan petani, semakin tinggi tingkat pelaksanaan maka semakin tinggi penerimaan petani dan sebaliknya. 
3 Rata-rata penerimaan petani kopi anggota tidak berbeda nyata dengan rata-rata penerimaan petani kopi non anggota. Hal tersebut ditunjukan oleh nilai t hitung $(1,863)$ lebih kecil dari tabel $(2,436)$. Demikian juga rata-rata penerimaan petani padi anggota tidak berbeda nyata dari penerimaan petani padi non anggota UPKD Andalas. Hal ini dilihat dari nilai t hitung $(1,049)$ lebih kecil dari t tabel $(2,896)$.

\section{Saran}

Untuk meningkatkan penerimaan petani, diharapkan pihak UPKD dan petani dapat melaksanakan hak dan kewajibannya sesuai buku petunjuk yang ada, untuk itu disarankan agar :

1. Pihak UPKD perlu lebih mensosialisasikan pelaksanaan hak dan kewajiban terutama untuk kegiatan simpan pinjam sektor pertanian. Sehingga dapat memberikan keuntungan baik untuk petani maupun pihak UPKD.

2. Sebaiknya petani membentuk kelompok tani, untuk mempermudah PPL dalam melakukan penyuluhan. Sehingga proses pembinaan dan penyuluhan dapat dilakukan secara intensif dan dapat dilakukan secara menyeluruh.

3. Untuk menghindari penyalagunaan dana kredit yang diberikan kepada petani, sebaiknya bantuan selain berbentuk dana kredit juga berbentuk sarana produksi yang dibutuhkan petani agar produksi meningkat.

\section{DAFTAR PUSTAKA}

Tim Koordinasi BRDP. 2003. Petunjuk Pelaksanaan dan Petunjuk Teknis Pelaksanaan Proyek BRDP Propinsi Bengkulu.Bengkulu.

Astuti. 1997. Studi keberhasilan Petani dalam Mengelola Dana IDT (Kasus Di Desa Air Mundo Kecamatan Perwakilan Pal VII Kabupaten Rejang Lebong). Skripsi. Jurusan Sosial Ekonomi Pertanian Universitas Bengkulu. (tidak dipublikasikan).

Folia, SA.2002. Evaluasi Pelaksanaan Kemitraan Inti Plasma PT. Agricinal dengan Petani. Jurnal Penelitian. Jurusan Sosial Ekonomi Pertanian Universitas Bengkulu.

Gunawan, I. 2003. Studi Komparatif Produksi, Penerimaan, Efisiensi Usaha Penangkap Udang yang Menggunakan Perahu Layar Di Desa Air Buruh dan yang Menggunakan Motor Tempel Di Desa Air Rambai Kecamatan Muko-Muko Selatan Bengkulu Utara. Skripsi. Jurusan Sosial Ekonomi Pertanian Universitas Bengkulu. (tidak dipublikasikan).

Hasibuan, I. 2003. Analisis Penerimaan Usahatani dan Keuntungan Pemasaran Semangka (Citrullus Vulgaris) Di Desa Suro Lembak Kecamatan Ujanmas Kabupaten Rejang Lebong. Skripsi. Jurusan Sosial Ekonomi Pertanian Universitas Bengkulu. (tidak dipublikasikan). 
Lofty, A. 2001. Analisis Produktifitas dan penerimaan Usahatani Padi Sawah pada Petani Penewrima KUT dan Non Penerima KUT. Skripsi. Jurusan Sosial Ekonomi Pertanian Universitas Bengkulu. (tidak dipublikasikan).

Nazir, M. 1988.Metode Penelitian. Ghalia Indonesia. Jakarta.

Siegel, Sydney. 1994. Statistik Non Parametrik untuk IImu-IImu Sosial. Terjemahan Zanzawi, S dan Landung, S. Gramedia. Jakarta.

Singarimbun, M dan EffSendi, S. 1989. Metode Penelitian Survai. LP3ES. Jakarta.

Soekartawi. 2003. Teori Ekonomi Produksi, Dengan Pokok Bahasan Analisis Fungsi Cobb Douglas. PT. Raja Grafindo Persada. Jakarta.

Subagio, P.1985. Statistik Deskriptif. BPFE. Yogyakarta.

Umar, H. 1998. Sumberdaya Manusia Dalam Organisasi. PT. Gramedia Pustaka Utama. Jakarta. 